\title{
Growth retardation in a New Guinea boarding school and its response to supplementary feeding
}

\author{
By L. A. MALCOLM \\ Regional Health Office, Lae, New Guinea \\ (Received 9 fuly 1969-Accepted 6 October r969)
}

\begin{abstract}
I. Children attending a boarding school in the New Guinea highlands, and receiving a protein-deficient diet of sweet potato and taro showed, when compared with village children, a progressive retardation of growth which was related to the number of years at school.

2. Feeding of supplementary protein resulted in a dramatic acceleration of growth in both height and weight, whereas the feeding of extra calories produced an increase in only weight and skinfold thickness.

3. This response to protein feeding appears to be greater than previously reported in the literature.
\end{abstract}

Dietary protein deficiency is a problem which is widespread in developing countries. Its presence is not always readily recognized, as the commonly described signs of malnutrition may only be obvious to the clinical observer when the degree of deficiency is relatively gross. The growth of children may be a sensitive index of protein deficiency but its application is limited by the availability of standards of reference. This study compares the longitudinal growth of children on a protein-deficient diet in a New Guinea boarding school with the growth of village children of the same area, and reports on the changes in various indices of growth with the feeding of protein and other supplements.

\section{EXPERIMENTAL}

\section{Subjects}

Bundi, situated at an altitude of $1220 \mathrm{~m}$, is the administrative centre of the Bundi census division, containing 6727 people living at altitudes from 600 to $2000 \mathrm{~m}$ in rugged mountainous country. The area was first contacted by the Catholic Mission which opened a station in 1933. A Government Station was established in 1956, with a hospital in 1958 and this led to the subsequent development of health and medical services throughout the area.

The Bundi people have been described in detail by Malcolm (1969). In common with other New Guinea highland people, they are short and stocky with skin colour varying from light to dark brown. The staple food is sweet potato (Ipomoea batatas) with taro (Colocasia spp.) as an important subsidiary, both tubers with a low protein content varying from 0.5 to $2 \%$. Maize, beans, bananas and green leaves are also eaten but tend to be seasonal and there are no significant sources of animal protein. The dietary intake of protein for adult males of the Chimbu people on a similar diet was shown to vary from $20 \mathrm{~g}$ daily (Hipsley \& Kirk, 1965 ) to $30 \mathrm{~g}$ daily (Venkatachalam, I962), which is low by all normal standards, only $5 \%$ of calories being derived from 
protein sources. Most vulnerable are infants, toddlers and pregnant women and protein-calorie malnutrition with a high mortality rate among toddlers was common before the introduction of health services (Malcolm, I969).

A boarding school was established by the Catholic Mission in $195^{6}$ and steadily expanded to a total present enrolment of 360 . The provision of food for such an institution presents tremendous problems, as availability of local food is limited and there is little suitable land adjacent to the station for gardens. As the only outside access to Bundi is by air, imported foods such as rice and meat are too expensive for normal use. Land for cultivation was obtained by the mission some years ago and has been developed to supply the bulk of the sweet potato and taro requirements for the school, but is situated $600 \mathrm{~m}$ below the station. Children who are not within reasonable walking distance of their home village spend the weekend in this garden gathering food and carrying it back to the station at the beginning of the school week. The school diet is therefore limited almost entirely to taro and sweet potato, with occasional green vegetables and rice on Church feast days. No meat or animal protein is given except to a small selected group who need it for health reasons. Meals are provided three times daily and there is no eating between meals. The only sign of clinical malnutrition was visible parotid enlargement which was present in Ir \% of children. Selection for school entry is based on age, which is accurately known in most cases, and willingness of parents to send their children. There does not appear to be any selection factor which admits those different from the population mean.

\section{Methods}

Food actually eaten by the whole school in a test week was weighed and the mean daily intake per child calculated. Children whose ages were known from birth dates recorded in the baptismal register kept by the mission were measured for height and weight on up to four occasions at 6-month intervals. The subscapular skinfold thickness was also measured on one occasion. Two separate feeding trials using various supplements were performed. In the first, two classes of comparable age and size were taken, one being a control and the other being given $25 \mathrm{~g}$ of protein daily for 5 days weekly for Io weeks, in the form of skim-milk powder. This was mixed to a soupy consistency and given with the evening meal. Classes were measured both before and after the experiment for height and weight, and blood was taken for estimation of haemoglobin and serum proteins. In the second experiment which lasted 13 weeks, four classes, different from the above, were taken. One received the normal school diet as a control and, of the remaining three, one was given skim-milk powder in the form of a mid-morning drink, one the 270 daily kcal equivalent of the skim milk in the form of $30 \mathrm{~g}$ of margarine mixed with the evening meal, while the fourth class received five meals of taro and sweet potato daily, instead of the normal three. The weight of the extra meals was $450 \mathrm{~g}$ daily, but, as the normal three meals were eaten with the remainder of the school, it is uncertain whether less was eaten during these meals because of the extra food received. Each supplement was given for 5 days in the week. Height, weight and skinfold thickness were measured before and after the trial, and blood was taken for estimation of haemoglobin and serum protein from the skim milk 
and control classes. The mean age and size for supplemented classes did not differ to any extent from that of the controls and there did not appear to be any factor in the selection of the classes which could have influenced the result. All classes followed similar activities, both during the school week and at the weekends.

\section{RESULTS}

The quantity and nutritional value of the school diet is shown in Table I. The energy and calcium content has been calculated from Bailey (1967), the protein $(\mathrm{N} \times 6.25)$ from the analysis of fifty-four samples of sweet potato and eleven samples of taro from the Bundi area (L. A. Malcolm, unpublished findings), the vitamin content

Table I. Daily quantity and nutritional value of the diet of the Bundi schoolchild

$\begin{array}{lcccccc} & \begin{array}{c}\text { Energy } \\ (\mathrm{kcal})\end{array} & \begin{array}{c}\text { Protein } \\ (\mathrm{g})\end{array} & \begin{array}{c}\text { Calcium } \\ (\mathrm{g})\end{array} & \begin{array}{c}\text { Vitamin A } \\ \text { (i.u.) }\end{array} & \begin{array}{c}\text { Thiamine } \\ (\mathrm{mg})\end{array} & \begin{array}{c}\text { Ascorbic } \\ \text { acid } \\ (\mathrm{mg})\end{array} \\ \begin{array}{l}\text { Taro } 800 \mathrm{~g} \\ \begin{array}{l}\text { Sweet potato } \\ 300 \mathrm{~g}\end{array}\end{array} & \mathbf{1 2 2 0} & 9 & 0.48 & - & 0.8 & 59 \\ \begin{array}{l}\text { Total } \\ \begin{array}{l}\text { Estimated } \\ \text { requirement }\end{array}\end{array} & \mathbf{3 9 0} & 3 & 0.18 & 2500 & 0.4 & 110 \\ \begin{array}{l}\text { Deficiency } \\ \text { 1610 }\end{array} & 1750 & 27 & 0.66 & 2500 & 1.2 & 169 \\ & 140 & 15 & - & - & - & -\end{array}$

Table 2. Mean heights ( $\mathrm{cm})$, weights $(\mathrm{kg})$ and subscapular skinfold thickness $(S F)$ $(\mathrm{mm})$ for age of Bundi village children and schoolchildren

\begin{tabular}{|c|c|c|c|c|c|c|c|c|c|c|c|c|c|c|}
\hline \multirow{3}{*}{$\begin{array}{c}\text { Age } \\
\text { (years) }\end{array}$} & \multirow[b]{3}{*}{ No. } & \multicolumn{6}{|c|}{ Village } & \multicolumn{7}{|c|}{ School } \\
\hline & & \multicolumn{2}{|c|}{ Height } & \multicolumn{2}{|c|}{ Weight } & \multicolumn{2}{|c|}{$\mathrm{SF}$} & \multirow[b]{2}{*}{ No. } & \multicolumn{2}{|c|}{ Height } & \multicolumn{2}{|c|}{ Weight } & \multicolumn{2}{|c|}{$\mathrm{SF}$} \\
\hline & & Mean & SD & Mean & SD & Mean & SD & & Mean & SD & Mean & SD & Mean & SD \\
\hline \multicolumn{15}{|c|}{ Boys } \\
\hline $5 \cdot 5-6 \cdot 5$ & 78 & $98 \cdot I$ & $4 \cdot 1$ & $15^{\cdot 8}$ & $I \cdot 6$ & 3.4 & $I \cdot I$ & 19 & $97 \cdot 3$ & 3.4 & I 5.5 & $I \cdot 3$ & $4 \cdot 4$ & $I \cdot I$ \\
\hline $6 \cdot 5-7 \cdot 5$ & 62 & ror 8 & $5 \cdot 4$ & $17 \cdot 0$ & $2 \cdot I$ & $3 \cdot 9$ & $\mathrm{I} \cdot \mathrm{O}$ & 26 & 100.5 & $5 \cdot 2$ & $16 \cdot 4$ & $1 \cdot 8$ & $4 \cdot 0$ & $I \cdot I$ \\
\hline $7 \cdot 5-8 \cdot 5$ & 68 & $105 \cdot 3$ & $5 \cdot 1$ & $18 \cdot 0$ & $2 \cdot 2$ & $4 \cdot 2$ & $I \cdot 2$ & 20 & 102.5 & $4 \cdot 3$ & $16 \cdot 8$ & $I \cdot 4$ & $4 \cdot 4$ & $1 \cdot 3$ \\
\hline $8 \cdot 5-9 \cdot 5$ & 47 & 109.9 & $4 \cdot 8$ & 19.3 & $2 \cdot I$ & 4.0 & 0.9 & 14 & 106.7 & $5 \cdot 3$ & $17 \cdot 9$ & $2 \cdot 0$ & $4^{\circ} 4$ & 0.7 \\
\hline $9.5-10.5$ & 34 & $112 \cdot 2$ & $5 \cdot 7$ & 20.9 & $2 \cdot 6$ & $4 \cdot 2$ & $1 \cdot 2$ & I 2 & IOg.I & $4 \cdot 3$ & $18 \cdot 7$ & $\mathbf{I} \cdot 6$ & $4 \cdot 5$ & $I \cdot 4$ \\
\hline $10.5-11.5$ & 20 & I 17.5 & $5 \cdot 7$ & $23 \cdot I$ & $3 \cdot 2$ & 4.0 & 0.9 & 9 & 119.8 & $5^{\circ} 0$ & $24 \div 3$ & $3 \cdot 2$ & $4 \cdot 3$ & $I \cdot I$ \\
\hline $11 \cdot 5-12 \cdot 5$ & 32 & I I $7 \cdot 2$ & $6 \cdot 0$ & 24.0 & $3 \cdot 0$ & 4.8 & $I \cdot I$ & 17 & I I 5.6 & $5 \cdot 7$ & $23 \cdot 7$ & $3 \cdot 2$ & $4 \cdot 9$ & $1 \cdot 2$ \\
\hline $12 \cdot 5-13.5$ & 36 & I $21 \cdot 3$ & $6 \cdot I$ & $25 \cdot 3$ & $2 \cdot 8$ & $5^{\circ} 0$ & $I \cdot 4$ & 22 & $12 \mathrm{I} \cdot 8$ & $5 \cdot 9$ & $25 \cdot 6$ & $2 \cdot 5$ & $5 \cdot 3$ & I' 5 \\
\hline $13.5-14.5$ & 28 & $125 \cdot 3$ & $4^{\cdot I}$ & $27 \cdot 3$ & $2 \cdot 9$ & $4^{*} 9$ & $1 \cdot 7$ & 6 & $127 \cdot 3$ & 4.4 & $28 \cdot 0$ & $2 \cdot 2$ & $5 \cdot 3$ & $2 \cdot 4$ \\
\hline $14^{\circ} 5^{-1} 5^{\circ} 5$ & 35 & I3 $I^{\circ} 0$ & $5 \cdot 9$ & 30.9 & $3 \cdot 9$ & $5 \cdot 1$ & $I \cdot 6$ & 9 & $129 \cdot 8$ & $I \cdot 5$ & $3 \times \cdot 9$ & I'9 & 6.7 & $I \cdot 5$ \\
\hline \multicolumn{15}{|c|}{ Girls } \\
\hline $5 \cdot 5-6 \cdot 5$ & 42 & $96 \cdot 8$ & $3 \cdot 8$ & $15 \cdot 1$ & $I \cdot 5$ & $4 \cdot 0$ & 0.9 & 5 & $92 \cdot 4$ & $2 \cdot 7$ & 13.2 & $I \cdot O$ & $4 \cdot 4$ & 0.8 \\
\hline $6 \cdot 5-7 \cdot 5$ & 63 & 103.3 & 44 & $16 \cdot 9$ & $I \cdot 9$ & 3.9 & $x \cdot I$ & I I & 103.5 & 3.7 & $16 \cdot 4$ & $I \cdot O$ & $3 \cdot 5$ & 0.8 \\
\hline $7 \cdot 5-8 \cdot 5$ & 53 & $107 \cdot 1$ & 6.0 & $18 \cdot 6$ & $2 \cdot 7$ & 4.4 & $I \cdot 2$ & I I & $102: 9$ & $7 \cdot 7$ & $x 7 \cdot 2$ & $2 \cdot 0$ & $4 \cdot 6$ & $I \cdot 6$ \\
\hline $8 \cdot 5-9 \cdot 5$ & 43 & 110.0 & $5 \cdot 8$ & $19 \cdot 7$ & $2 \cdot 6$ & $4 \cdot 6$ & 0.9 & 5 & $107 \cdot 2$ & $6 \cdot 6$ & $18 \cdot 5$ & $2 \cdot 2$ & $4 \cdot 2$ & 0.7 \\
\hline $9 \cdot 5-10.5$ & 33 & I $12 \cdot 6$ & $5 \cdot 7$ & $2 I \cdot I$ & $2 \cdot 8$ & $5 \cdot I$ & $1 \cdot 5$ & 8 & 110.9 & $3 \cdot 2$ & $21 \cdot 4$ & $\mathrm{I} \cdot 5$ & $6 \cdot I$ & $I \cdot 6$ \\
\hline $10.5-11.5$ & 13 & I $17 \cdot 3$ & $7 \cdot 8$ & $22 \cdot 2$ & $2 \cdot 9$ & $5 \cdot I$ & $\mathrm{I} \cdot 3$ & 8 & I I $4 \cdot 6$ & $6 \cdot 5$ & $2 I \cdot I$ & $I \cdot 8$ & $5 \cdot 8$ & $1 \cdot 3$ \\
\hline $11 \cdot 5-12.5$ & 21 & 116.9 & $6 \cdot 2$ & $22 \cdot 8$ & $2 \cdot 9$ & $5^{\cdot 8}$ & $I \cdot 4$ & 10 & I I 4.9 & $2 \cdot 6$ & $22 \cdot 8$ & $2 \cdot 4$ & $5 \cdot 6$ & 1.0 \\
\hline $12.5-13.5$ & 37 & $124 \cdot 3$ & $7 \cdot 4$ & $26 \cdot 6$ & $3 \cdot 6$ & $6 \cdot 1$ & I. 5 & 12 & $124^{-2}$ & $7 \cdot 4$ & $26 \cdot 4$ & $3 \cdot 6$ & $6 \cdot 8$ & $I \cdot 6$ \\
\hline $13 \cdot 5-14.5$ & 40 & 130.3 & $6 \cdot 0$ & $30 \cdot 1$ & $3 \cdot 9$ & $6 \cdot 9$ & $2 \cdot 2$ & 4 & $\mathrm{I} 27 \cdot 5$ & $6 \cdot 2$ & 28.9 & $4^{-9}$ & $8 \cdot 5$ & $3 \cdot 2$ \\
\hline \multirow[t]{2}{*}{$14^{.5}-15.5$} & 29 & 135.5 & 6.8 & 33.4 & $4 \cdot 2$ & $7 \cdot 7$ & $3 \cdot 8$ & 3 & $13 I \cdot 0$ & $5 \cdot 7$ & $31 \cdot 7$ & $3 \cdot 8$ & $7 \cdot 0$ & 0.8 \\
\hline & & & & & & & & & & & \multicolumn{4}{|c|}{$20-2$} \\
\hline
\end{tabular}


from Peters (1957) and the estimated requirements from Hipsley (196I) for New Guinea children. These requirements are based on the average weight of $22 \mathrm{~kg}$ of the Bundi schoolchild. No allowance has been made for the actual protein content of the

Table 3. Deviation of height and weight from village mean of Bundi schoolchildren for years at school

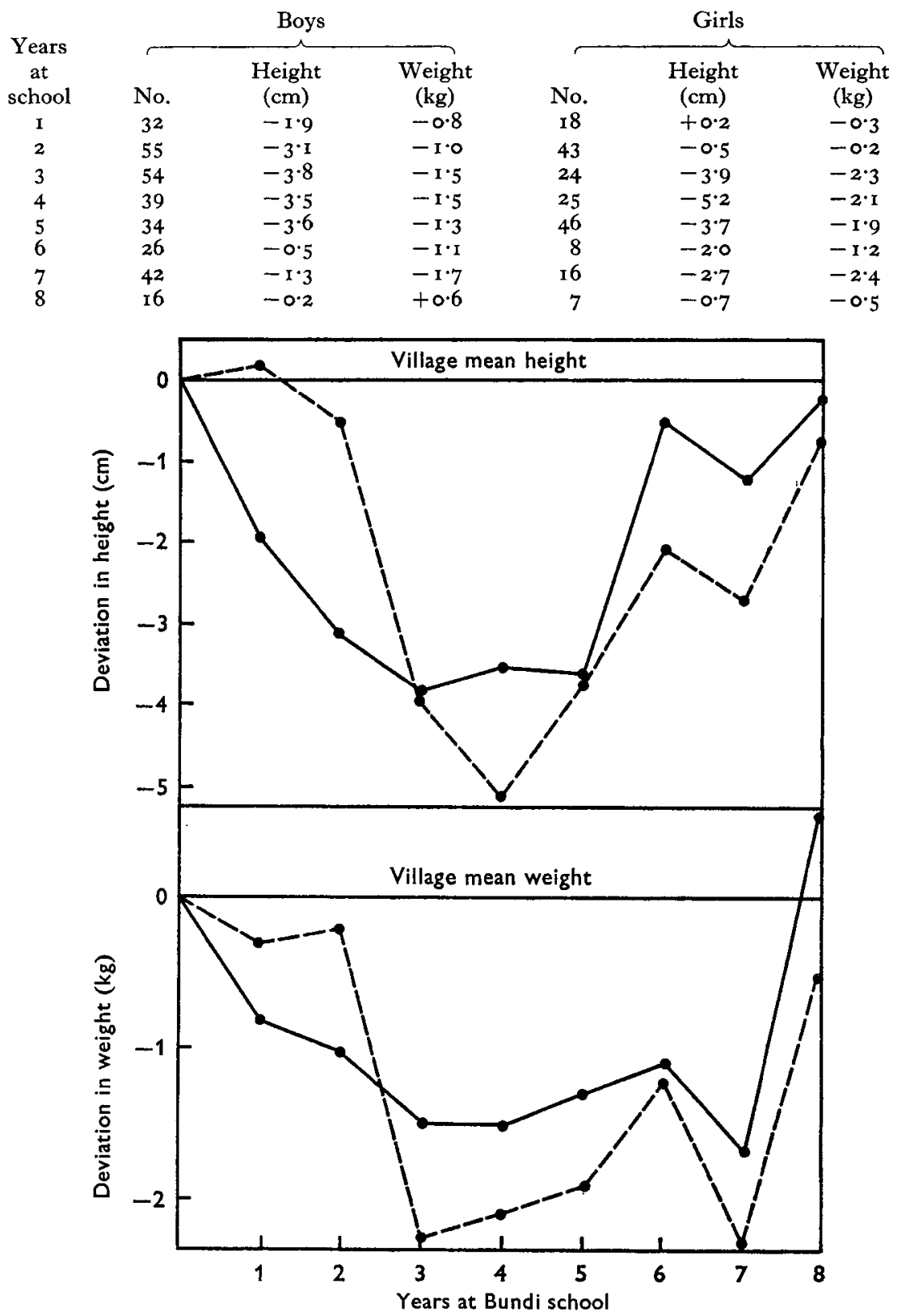

Fig. I. Mean deviation from the village mean in height and weight of the Bundi schoolchild for years at Bundi School. —-, boys; - - girls. 
tubers, which may only be $80 \%$ of the $\mathrm{N} \times 6.25$ value (Oomen, Spoon, Heesterman, Ruinard, Luyken \& Slump, 1961), or the biological value of the protein which is known to be deficient in sulphur-carrying amino acids (Oomen et al. 1961). The actual amount of protein available therefore to the schoolchild, was probably less than ro $\mathrm{g}$

Table 4. Expt I. Response of Bundi schoolchildren to supplementary protein. Mean initial age, height and weight with mean height and weight change

(Standard error of change in parentheses)

\begin{tabular}{|c|c|c|c|c|c|c|}
\hline Group & No. & $\begin{array}{c}\text { Age } \\
\text { (years) }\end{array}$ & $\begin{array}{c}\mathrm{Ht} \\
(\mathrm{cm})\end{array}$ & $\begin{array}{l}\text { Wt } \\
(\mathrm{kg})\end{array}$ & $\begin{array}{l}\text { Ht change } \\
(\mathrm{cm})\end{array}$ & $\begin{array}{c}\text { Wt change } \\
(\mathrm{kg})\end{array}$ \\
\hline Skim milk & 21 & $8 \cdot I$ & $104 \cdot 8$ & I $7 \cdot 6$ & $\begin{array}{r}+2.42 \\
(0.13)\end{array}$ & $\begin{array}{r}+0.73 \\
(0.22)\end{array}$ \\
\hline Control & 22 & $7 \cdot 5$ & 106.2 & I $7 \cdot 1$ & $\begin{array}{c}+1.18 \\
(0.12) \\
P<0.001\end{array}$ & $\begin{array}{c}-0.13 \\
(0.16) \\
P<0.01\end{array}$ \\
\hline
\end{tabular}

Table 5. Expt 2. Response of Bundi schoolchildren to various supplements for a 13 -week period. Mean initial age, height and weight with mean height, weight and skinfold $(S F)$ change

$$
\text { (Standard error of change in parentheses) }
$$

\begin{tabular}{|c|c|c|c|c|c|c|c|}
\hline Group & No. & $\begin{array}{c}\text { Age } \\
\text { (years) }\end{array}$ & $\begin{array}{l}\mathrm{Ht} \\
(\mathrm{cm})\end{array}$ & $\begin{array}{r}\text { Wt } \\
(\mathrm{kg})\end{array}$ & $\begin{array}{l}\text { Ht } \\
\text { change } \\
(\mathrm{cm})\end{array}$ & $\begin{array}{l}\text { Wt } \\
\text { change } \\
(\mathrm{kg})\end{array}$ & $\begin{array}{l}\text { SF } \\
\text { change } \\
(\mathrm{mm})\end{array}$ \\
\hline $\begin{array}{l}\text { (1) Skim milk, } 75 \text { g daily } \\
\text { + normal diet }\end{array}$ & $3^{1}$ & $7 \cdot 6$ & $105 \cdot 6$ & $17 \cdot 5$ & $\begin{array}{l}+2.32 \\
(0.11)\end{array}$ & $\begin{array}{l}+1 \cdot 21 \\
(0 \cdot 10)\end{array}$ & $\begin{array}{r}-0.13 \\
(0.14)\end{array}$ \\
\hline $\begin{array}{l}\text { (2) Margarine, } 3 \circ \mathrm{g}+ \\
\text { normal diet }\end{array}$ & 22 & $9 \cdot 8$ & 110.0 & $18 \cdot 9$ & $\begin{array}{r}+0.96 \\
(0.11)\end{array}$ & $\begin{array}{r}+I .05 \\
(0.18)\end{array}$ & $\begin{array}{l}+2 \cdot 28 \\
(0 \cdot 35)\end{array}$ \\
\hline $\begin{array}{l}\text { (3) } 5 \text { meals of taro and } \\
\text { sweet potato instead } \\
\text { of } 3\end{array}$ & 22 & $7 \cdot 4$ & 105.0 & $17 \cdot 7$ & $\begin{array}{r}+1.54 \\
(0.13)\end{array}$ & $\begin{array}{l}+0.47 \\
(0.14)\end{array}$ & $\begin{array}{l}+0.77 \\
(0.17)\end{array}$ \\
\hline (4) Control, normal diet & 35 & $8 \cdot 6$ & $108 \cdot 4$ & $18 \cdot 7$ & $\begin{array}{r}+1 \cdot 10 \\
(0 \cdot 12)\end{array}$ & $\begin{array}{l}+0.50 \\
(0.13)\end{array}$ & $\begin{array}{r}+0.17 \\
(0.13)\end{array}$ \\
\hline
\end{tabular}

Table of significance between increments in different groups

(2)

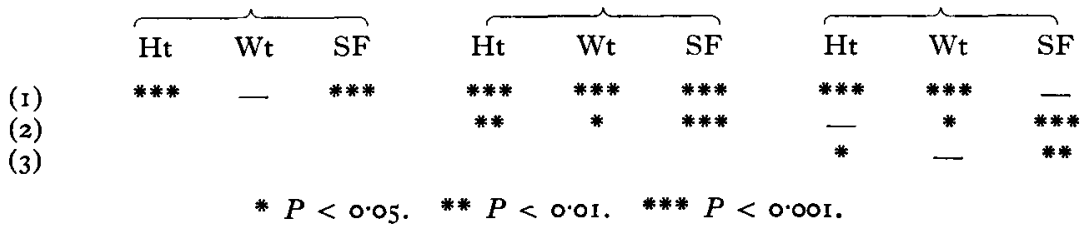

daily. There was also a calculated deficit of $140 \mathrm{kcal}$. There did not appear to be any significant mineral or vitamin deficiencies in the diet.

Heights and weights and skinfold thickness for school and village children (Malcolm, I969) are shown in Table 2. Values for height and weight for some ages were significantly lower than the values for the Bundi village child, whose growth rate is slower than that of any other reported population in the world (Malcolm, I969). From the longitudinal information available for the schoolchild, individual deviations in height 
and weight for age from the village mean were determined graphically, and grouped according to the number of completed years at school. The calculated mean values of these deviations are listed in Table 3 and shown graphically in Fig. I. It will be noted that there was a gradual fall in height and weight away from the village mean, during the first 4 years of school, but thereafter there was a tendency to recover, which was almost complete by the 8 th year. This recovery was statistically significant in boys.

The results of the first supplementary feeding experiment are shown in Table 4 and of the second in Table 5. Changes in various measurements are expressed as the mean increment or decrement (of change) of the individual values. The height increments of 2.42 and $2.32 \mathrm{~cm}$ in both protein-supplemented classes represent a marked

Table 6. Initial mean haemoglobin and serum protein values $(\mathrm{g} / 100 \mathrm{ml})$ with mean change following protein supplementation (both experiments combined)

$\begin{array}{lccccccc}\quad \text { Group } & \text { No. } & \mathrm{Hb} & \text { Albumin } & \text { Globulin } & \begin{array}{c}\mathrm{Hb} \\ \text { change }\end{array} & \begin{array}{c}\text { Albumin } \\ \text { change }\end{array} & \begin{array}{c}\text { Globulin } \\ \text { change }\end{array} \\ \text { Skim milk } & 50 & 12.5 & 3.64 & 3.34 & -0.12 & +0.24 & +0.30 \\ \text { Control } & 47 & 12.1 & 3.63 & 3.14 & +0.30 & +0.25 & +0.26\end{array}$

increase over the $\mathrm{I} \cdot \mathrm{I} 8 \mathrm{~cm}$ and $\mathrm{I} \cdot \mathrm{IO} \mathrm{cm}$ of the control classes for the two periods. Weight increments of 0.73 and $\mathrm{I}_{2} \cdot \mathrm{I} \mathrm{kg}$ are also considerably in excess of the controls. In the second experiment no significant change in height from the control resulted from the feeding of margarine, but there was a significant increase in weight and a dramatic increase in skinfold thickness. The feeding of two additional meals resulted in a slight but significant increase in the rate of growth in both height and skinfold thickness, but not of weight. The haemoglobin and serum protein values (Table 6), which did not differ from those of the village child of school age (Malcolm, 1969), did not change significantly in either experiment.

A 3-month follow up of the groups in the first experiment showed that growth in height of $0.99 \mathrm{~cm}$ for the supplemented group and $\mathrm{I} .06 \mathrm{~cm}$ for the control group continued at the average rate for the school when the supplement was withheld. However, growth in weight was significantly less in the supplemented group, $0.10 \mathrm{~kg}$, than in the control group, $0.64 \mathrm{~kg}$, for the same period. This was possibly due to the fact that during 2 months of this period the children were at home in the village, and compensatory growth in weight occurred in the control group on the village diet.

\section{ISCUSSI ON}

The changes in height and weight with years of school are clearly related to the school environment and are almost certainly a reflection of the dietary differences between school and village. Several factors may account for this difference.

(I) The schoolchild, confined by school routine, is unable to forage for the titbits of animal protein such as frogs, spiders and insects. The amount of protein, however, obtained from this source by the village child is not considered to be significant. Several samples were examined but it appeared that the total quantity consumed 
in any one day could not have materially added anything to the child's protein intake.

(2) Children admitted to school, in some instances shortly after weaning, are exceedingly small for their age and there may be some element of maternal and emotional deprivation, which Widdowson (195I) has shown can interfere with the growth rates. It would be expected that such children would be reticent and retarded in other respects, but this is clearly not so from statements made by the school staff and from observations over a number of years.

(3) The variety of food available at the school is limited almost entirely to taro and sweet potato, whereas the village child does have access to maize, green vegetables, occasional pig and other village foods. However, this variation of diet is usually only available during the dry season, and is limited for at least 6 months of the year.

(4) The main factor, however, appears to be the feeding pattern of three meals only during the day. The nutritional requirements of the small child on a bulky starch diet may not be satisfied by such infrequent feeds. The stomach in starch eaters performs only a mechanical function, preparing the food for passage into the duodenum and intestine, this process being completed $2 \mathrm{~h}$ after a full meal. At this stage the stomach is ready to receive further food but this is denied because of the meal schedule, food not being available for an average of $4-5 \mathrm{~h}$ after the previous meal. In comparison, however, the village child, it was consistently noted, eats almost continually. It is suggested that the recovery by the 8th year in school is due to growth of the stomach and to the increasing ability of the child to satisfy its nutritional needs by less frequent feedings.

(5) A further possibility related to the feeding schedule is suggested by the experiments of Cohn, Joseph, Bell \& Oler (I 963) and Cohn, Joseph, Bell \& Frigerio (I 964) in which nitrogen retention in rats was increased by feeding ad lib. and decreased by limiting the number of meals to two daily. The protein intake on a three-meal schedule may not all be utilized for anabolic purposes but may be metabolized for energy or storage. Some confirmation of this is found in the generally higher skinfold thickness values in the Bundi schoolchild, compared with the village figures.

The results of the feeding experiments indicate that protein is a key factor in determining growth in height. It is clear that the height gain was directly related to the quantity of supplementary protein supplied, while additional calories from fat did not result in any protein-sparing effect, merely in increase in weight through the storage of redundant intake as subcutaneous fat. The increase in height with the extra meals, was possibly due to the slower absorption of the additional protein from the bowel and hence its more efficient utilization for protein synthesis, or alternatively due to the specific protein-sparing effect of the additional carbohydrate. The lack of increase in weight over the control in the presence of the increased skinfold thickness is however unexpected.

Increase in weight in these experiments could have been due to either the accumulation of subcutaneous fat or the synthesis of muscle tissue which, with its high water content, could result in a much greater weight gain than that of the actual assimilated protein. However, the interaction between food nutrients and the existing tissue 
structure is a complex one, and it would be unwise to make further assumptions on the basis of these limited experiments.

The height for weight increment of the protein-supplemented groups did not differ significantly from that of the normal growth pattern, i.e. the height for weight proportions were not altered.

As these experiments were performed on schoolchildren whose heights and weights were depressed below the village mean, at least part of the result may be accounted for by a compensatory growth with the additional food. There is no certainty that the acceleration of growth would continue indefinitely, but this question may be answered by further prolonged protein feeding.

Supplementary feeding experiments reported by many workers in different situations have not always shown such positive results. Aykroyd \& Krishnan (1937), in a 3 -month trial of skim-milk feeding in an Indian boys' boarding school, reported significant increases in height and weight and an improvement in nutritional status over a control group. The height increment, however, was much less than that of the Bundi child.

Subrahmanyan, Joseph, Doraiswamy, Narayanarao, Sankaran \& Swaminathan (1957), in a 5-month feeding trial with a multinutritive food on a group of poorly nourished Indian orphanage children, showed a significant increase in height, weight and haemoglobin over a control group. However, Bailey (1962), in a feeding trial with Indonesian schoolchildren on a cassava diet only, was unable to demonstrate a significant increase in height and weight. Only small protein supplements were used, however, up to $12.5 \mathrm{~g}$ daily, and this may have been insufficient to accelerate growth. Becroft \& Bailey ( 1965 ), in a 12 -month feeding trial on infants and toddlers in the Baiyer Valley of New Guinea, reported a completely negative result from the feeding of various protein supplements. Other trials, cited by Becroft \& Bailey (1965), have shown increases in weight in children of school age, without always an increase in height, but the supplements included many extras and it was not clear which specific nutrient supplied was responsible.

Scrimshaw \& Guzman (I953), in feeding trials in growth-retarded Guatamalan schoolboys, showed no significant increase in growth, in either height or weight, when various protein foods and other supplements were given over a period of 2 years.

Bailey (1962), in reviewing these negative results, attributed the failure to either insufficient supplement or to the metabolic derangements produced by chronic malnutrition from infancy, which prevented the body from responding to such supplementation. The results in the Bundi child do not support Bailey's latter suggestion. However, it appears that the protein supplements given to the Bundi child were in excess of those used in most of the above feeding trials and this may account for the different results.

A. M. Thomson (1967, personal communication) refers to a 12-month feeding trial in English towns, where an average increase of only $0.38 \mathrm{~cm}$ and $0.63 \mathrm{~kg}$ was attained over a control group.

Tanner (I962) lists a number of trials on European children, where supplementary protein accelerated growth, but only in circumstances in which the diet was initially 
inadequate. However, it was not clear whether the growth-promoting factor was the protein or some other factor, such as calcium, included in the supplement.

There is obviously no clear consensus from the above reports, and the negative results in developing countries, in comparison with the European results, are at variance with what would be expected when the nutritional situations are compared. It is perhaps possible that in experiments in developing countries there is a greater degree of unreliability in the taking of the supplement, and its sharing with either the control groups or relatives. The results in the Bundi children, however, appear to be greater than in any previously reported trials, both in the effect on the rate of growth with a rapid response in such a short period (IO-I3 weeks), and in the combined effect on height and weight in equal measure.

These findings, in a situation where overt signs of malnutrition are absent, point strongly to the presence of protein deficiency, and to the extent of the growth response as a measure of this deficiency and the effectiveness of treatment. Growth is, of course, not the only index of nutritional deficiency and efforts are at present being made to evaluate a range of biochemical and other indices (Jelliffe, I966) in this school.

The author wishes to acknowledge the assistance of Father M. Morrison and staff of the St Francis of Assisi boarding school, Bundi, in the conducting of this study and thanks Dr Peter Booth of the Red Cross Transfusion Service, Port Moresby, for the serum protein estimations.

\section{REFERENCES}

Aykroyd, W. R. \& Krishnan, B. G. (1937). Indian F. med. Res. 24, 1093.

Bailey, K. V. (1962). Trop. geogr. Med. 14, I29.

Bailey, K. V. (1967). Trop. geogr. Med. 20, r41.

Becroft, T., Bailey, K. V. (I965). F. trop. Pediat. Ir, 28.

Cohn, C., Joseph, D., Bell, L. \& Frigerio, N. A. (I964). Proc. Soc. exp. Biol. Med. II5, 1057.

Cohn, C., Joseph, D., Bell, L. \& Oler, A. (1963). Am. F. Physiol. 205, 7I.

Hipsley, E. H. (196r). Fd Nutr. Notes Rev. 18, 97.

Hipsley, E. H. \& Kirk, N. E. (1965). Tech. Pap. S. Pacif. Commn no. 147.

Jelliffe, D. B. (1966). Monograph Ser. W.H.O. no. 59.

Malcolm, L. A. (1969). Genesis and variation. MD Thesis, University of Otago.

Oomen, H. A. P. C., Spoon, W., Heesterman, J. E., Ruinard, J., Luyken, R. \& Slump, P. (r96r). Trop. geogr. Med. 13, 55.

Peters, F. E. (1957). Tech. Pap. S. Pacif. Commn no. 199.

Scrimshaw, N. A. \& Guzman, M. A. (1953). Nutr. Symp. Ser. no. 7, p. Iог.

Subrahmanyan, V., Joseph, K., Doraiswamy, T. R., Narayanarao, M., Sankaran, A. N. \& Swaminathan, M. (1957). Br. F. Nutr. Ir, 382 .

Tanner, J. M. (1962). Growth at Adolescence. Oxford: Blackwell Scientific Publications.

Venkatachalam, P. S. (1962). Monograph Ser. Dep. Publ. Hlth Port Moresby no. 4.

Widdowson, E. M. (I95I). Lancet i, I3 I6. 